\title{
Long-Run Determinants of Equity Foreign Portfolio Investment (EFPI) in Sri Lanka: A Time Series Analysis with Autoregressive Distributive Lag (ARDL) Approach
}

\author{
G. D. Kapila Kumara ${ }^{a}$, D. A. I. Dayaratne ${ }^{\text {b1 }}$ \\ ${ }^{a}$ Masters in Economics Programme, Department of Economics, University of Colombo \\ ${ }^{b}$ Department of Accountancy and Finance, Sabaragamuwa University of Sri Lanka
}

\begin{abstract}
Equity Foreign Portfolio Investment (EFPI) is useful in enhancing the efficiency and liquidity of capital markets. This study explores the long-run determinants of EFPI in Sri Lanka using the autoregressive distributed lagged (ARDL) model. The dataset covers monthly time series data from 2004 to 2013 . The findings suggest that the London Inter-Bank Offered Rates (LIBOR), foreign reserves presented in months of imports, USD/LKR exchange rate and domestic share market performance measured by the All Share Price Index (ASPI) are statistically significant and have a long-run positive effect on EFPI. The remaining variables, three-month Treasury bill rates, the Colombo Consumer Price Index (CCPI) and the S\&P500 index are statistically insignificant. It is further revealed that there is a short-run causality running from months of imports, threemonth Treasury bill rates, USD/LKR exchange rates and CCPI towards EFPI at the Colombo Stock Exchange (CSE).
\end{abstract}

Keywords: Equity Foreign Portfolio Investment (EFPI), Market Capitalization, Colombo Stock Exchange (CSE), Autoregressive Distributed Lagged (ARDL) Model

\section{Background of the Study}

The capital market facilitates long-term fund raising for investment and is a major component of the financial system in an economy. It is an accepted fact that a capital market contributes to an economy in many ways. As noted by Bryan and Debbie (1990), the capital market enables the domestic corporate sector to raise funds in the form of equity, instead of borrowings. Domestic savers are also benefited from liquidity and positive returns against inflation, which most other investment instruments fail to offer. A capital market facilitates private enterprises to become public so that they 
can expand operations to the next level. The capital market is a useful in attracting foreign savings to bridge the savings-investment gap. Further, it paves the way to enter international capital markets.

The Colombo Stock Exchange (CSE) is the only securities exchange in the Sri Lankan capital market where equity and debt securities of listed companies are traded. As a developing nation, Sri Lanka welcomes foreign investment. Generally, foreign capital flows come in two forms; Foreign Direct Investments (FDI) and Foreign Portfolio Investments (FPI). FDIs occur when a company in one country purchases a company in another country or forms a new company in the targeted country. Generally, FDIs are long-term in nature and bring management and technology in addition to funds. International savings, on the other hand, come as portfolio investments on listed securities (equity or debt) traded in an exchange in the targeted country. Unlike FDI, FPI can be easily withdrawn by selling securities at an exchange. Thus, FPI is more vulnerable when compared to FDI.

FPI is useful in many ways for the host country. According to Evans (2002), it enhances the efficiency and liquidity of the capital market through turnover improvement. The shareholders' demand for better corporate governance encourages transparency and disclosure requirements. In addition, it forces listed companies to adhere with recognized accounting standards while maintaining management best practices. Further, it transmits new and advanced knowledge, skill and technology on portfolio management to the domestic market. It also encourages the introduction of new products which is useful to mitigate risk via portfolio diversification. Most developing nations attempt to attract FPI to gain one or more of these benefits.

In Sri Lanka, foreign investors hold a significant portion of the CSE's market capitalization. As CSE's data shows, foreign investors' contribution to market turnover has fluctuated from 10 to 54 per cent over the past decade. In this context, foreign investors' contribution is noteworthy in enhancing liquidity and efficiency in the CSE. The effect of FPI is not limited only to the capital market. The short-term and vulnerable nature of FPI may affect other domestic financial markets like money markets and foreign exchange markets. Therefore, an understanding of the determinants of FPI is vital as it makes a significant impact on domestic financial markets.

Thus, this paper attempts to identify the long- run determinants of Equity Foreign Portfolio Investments (EFPI) in the CSE using an accepted and relevant model in econometrics which is the Autoregressive Distributed Lagged (ARDL) Model. This paper also explores the causality of selected domestic and global factors towards EFPI at the CSE. This paper contributes to the existing body of knowledge in several ways: (a) the literature review suggests that no prior studies have been conducted in the CSE with respect to determinants of EFPI, (b) the ARDL model is applied for the first time to fulfill the research purpose, (c) the sample period covers both the war period and post war periods. Therefore, new knowledge generated through this research would be useful for policy makers and market intermediaries to estimate and forecast the future movements of foreign participation at the CSE. Further, this research bridges the knowledge gap in Sri Lankan literature on capital market and paves way for further studies.

Subsequent sections of this paper are organized as follows. Section 2 provides a brief review of relevant literature in the field. Section 3 describes the theoretical framework of the research and its conceptual model. The description of data follows in Section 4. Section 5 illustrates the econometric 
methodology employed and section 6 interprets the results thereof. Section 7 presents discussion of findings. Finally, section 8 and 9 provide the conclusion and policy implications respectively.

\section{Review of Literature}

Previous studies show that the effect of FPI on a host country's economy and the determinants of FPI varying according to context. Parthapratim (2011) argues that the volatile and uncertain nature of FPI creates serious problems for macroeconomic management in India. Duasa and Kassim (2009) found that FPI in Malaysia does not cause changes in economic performance, although economic growth on the other hand causes change in FPI. They conclude that economic development in Malaysia is independent from FPI, but encourage more FPI. Benson (2003) too confirms these findings.

Bartram and Gunter (2001) developed the International Capital Assets Pricing Model (ICAPM) which explains the transfer of the CAPM logic to the international investment context. Thus, expected return of a foreign stock is the cumulative result of the risk premium on the world market portfolio, risk premium of the relevant currency and the risk free premium. Sharan (2005) explains that the ultimate objective of portfolio investment, from a fund manager's point of view, is to build up a better portfolio where risk-return trade-off is optimal, as explained by the CAPM. Thus, the factors which determine foreign portfolio investment can be identified through the determinants of risk and return relating to an investment. Apart from the factors associated with risk and return, institutional constraints imposed by capital market regulators in both host and source countries also affect in determining the quantum of FPI.

Sharan (2005) also states that changes in exchange rate should also be taken into account in calculating the expected return on FPI, since exchange rates at the time of investing and those at the time of realizing returns on investment may be different. Kim (1999) introduced a model which describes the determinants of international capital flows. Kim identifies two broad factors, telecommunication technology and information and market openness, as well as the rate of return and the risk factors in affecting potential investment. In analyzing further, Kim also discovered three main factors, real interest rate differential, financial and transaction cost, and regulation cost, which determine the rate of return. According to Kim the economic and political stability of the host country determines the risk factor of international capital flows.

Similarly, Fernandez-Arias and Montiel (1995) developed the model of 'push and pull factors in capital flows'. The factors which encourage outflow of funds from a source country are known as 'Push Factors' while the factors that create a demand for FPI from the host countries are known as 'Pull Factors'. Generally, macroeconomic variables in host country are considered as Pull Factors. S. Kim, Kim, and Choi (2013) studied the push vs. pull factors of international capital flows in the South Korean context and found that real interest rate and stock price index in South Korea have significant positive effects on portfolio capital flows whilst the current account has a significant negative effect. On the other hand, among external factors, a positive effect is observed with the real world GDP growth rate and net portfolio inflows.

Similarly, Ekeocha, Malaolu, Oduh and Onyema (2012), attempted to model the long-run determinants of FPI in Nigeria and findings reveal a long-run positive relationship between growth of real non-oil GDP, real interest rate, degree of financial liberalization and institutional quality (law and 
contract enforcement), over FPI in Nigeria. Gumus, Duru, and Gungor (2013) analyzed the relationship between FPIs and macroeconomic factors in Turkey and the findings of the analysis document that FPI influences the Istanbul Stock Exchange Price Index and exchange rates. Further, out of the variables considered, the FPI is only affected by the industrial production index.

Conversely, Bryan and Debbie (1990) document that foreign portfolio investors look in to certain general country, economic and political considerations in making investment decisions. A country's favorable attitude towards the private sector is a key driver of economic development and signifies prospect of reasonable economic growth, and serves as a positive influence towards FPI. Sakuragawa and Watanabe (2010) investigated the effect of common determinants of foreign direct and equity portfolio investments using panel data of 75 countries including Sri Lanka. The findings show that market liberalization policies affect in changing the composition of capital flows.

With respect to India, Agarwal (1997) found a significant positive relationship between FPI and three other factors i.e. real exchange rate, index of economic activity and the share of domestic capital market in the world stock market capitalization. Further, he observed a significant negative relationship with inflation. He also found that FDI, total foreign trade and current account deficit are statistically insignificant in determining FPI to India. Pami and Reetika (2013) analyzed foreign portfolio investment flows to India to identify its determinants. The findings conclude that FPI is attracted by a well-performing domestic stock market, an appreciating exchange rate and strong domestic economic growth while high volatility in the exchange rate discourages FPI. Further, they found that a greater difference between domestic and foreign interest rates also attracts FPI. As per findings, variables such as reserves to import ratio, which measure creditworthiness, do not influence any component of portfolio flows.

In summary, the above literature survey reveals that FPI has gained the interest of practitioners and academicians to a greater extent. It also reveals that the previous studies are not conclusive on some determinants of FPI significant way. The current study is novel to the CSE and to the best knowledge of the authors the statistical tools adopted in this paper are also unique.

\section{Theoretical Framework and the Model}

The research is based on the theoretical framework shown in Figure 1 which is developed in a manner consistent with preceding literature review. This theoretical framework explains the long-run determinants of EFPI at the CSE.

This paper considers only seven factors in exploring the relationship, out of the factors that affect on EFPI as describes by the theoretical framework. For instance, the GDP growth rate in Sri Lanka (the host country) as well as in the source countries are not considered as explanatory variables in this research paper due to unavailability of monthly data. Country risk, market risk, transaction cost and other institutional constraints are also not considered due to unavailability of secondary data and difficulty in measuring and factoring certain qualitative variables in to a model being the main reasons. Further, in practice, investment decisions are based on investment policies and strategies unique to each investment fund, investment company, or investment manager. These institutional and personal policies and strategies are not captured in this research paper, and together with the above, can be considered the main limitations of this study. The authors therefore encourage further research on the relationship between GDP growth and FPI in Sri Lanka. 
Figure 1: Theoretical Framework: Determinants of Equity Foreign Portfolio Investment in Sri Lanka

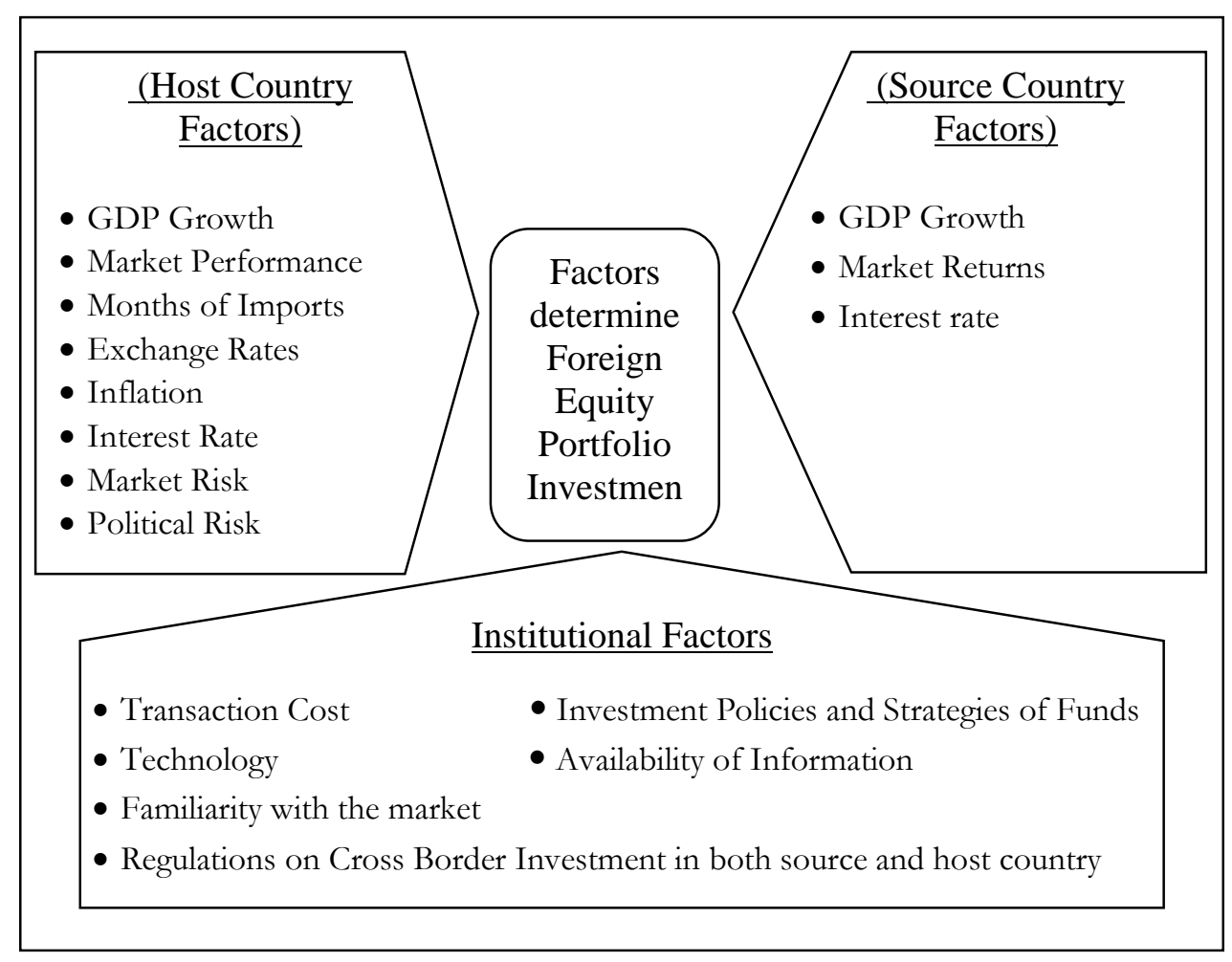

The following model is constructed on the selected variables:

\section{Equation 1:}

$\mathrm{EFPI}_{t}=\beta_{0}-\beta_{1} \mathrm{LIBOR}_{t}+\beta_{2}$ MIMP $_{t}+\beta_{3} \mathrm{TBR}_{\mathrm{t}}-\beta_{4}$ FOREX $_{t}-\beta_{5} \mathrm{CCPI}_{t}+\beta_{6} \mathrm{ASPI}_{t}-\beta_{7} \mathrm{SP}_{500}+\mathrm{e}_{\mathrm{t}}$

Where,

EFPI Equity Foreign Portfolio Investment (Purchases)

ASPI All Share Price Index

SP500 S\&P 500 Index

MIMP Months of Imports

TBR Three Months Treasury Bill Rates

LIBOR London Inter-Bank Offered Rates

FOREX Exchange Rates-USD/LKR

CCPI Colombo Consumer Price Index

$\boldsymbol{\beta}_{0} \quad$ white noise (Intercept)

e $\quad$ Error Term

The explanatory variables in the model have been carefully selected referring to previous theoretical models, empirical papers and also practical view points. 'The risk and return approach in determining FPI' which is based on Sharan's (2005) capital asset pricing model and Kim's (1999) 
'model for determinants of international capital flows' formulate the rationale for selecting the explanatory variables. Kaur and Dhillon (2010) and Agarwal (1997) had used inflation, world interest rate, exchange rate, domestic stock market performance and the S\&P500 as explanatory variables whilst Kim, et al. (2013), Pami and Reetika (2013) and Ekeocha et al. (2012) had used world interest rate, real interest rate, exchange rate and domestic market performance as explanatory variables to ascertain the effect on FPI. According to the theoretical explanations and empirical observations that follow, generally the MIMP, TBR, ASPI are expected to have a positive relationship with EFPI while LIBOR, FOREX, CCPI and SP500 are generally expected to have a negative effect.

\section{Data and the Sample}

Monthly data from 2004 to 2013 have been used for time series analysis in this paper. The period covers a highly volatile period in the CSE as it includes three important regimes namely, the extensive war period in Sri Lanka, the 2008 global financial crisis and post-war period. This enables an observation of the modalities of the relevant determinants under high market volatility. The research is based on secondary data from Central Bank of Sri Lanka's (CBSL) annual reports, CBSL's monthly bulletins, reports of the Department of Census and Statistics and data extracted from Colombo Stock Exchange Data Library and the Bloomberg terminal.

\subsection{Description of Data}

The EFPI in the CSE is the dependent variable of this research. In calculating EFPI, all the foreign inflows made by both institutional and individual foreign investors to buy shares at the secondary market of the CSE have been considered. According to the United Nations Conference on Trade and Development's (UNCTAD) (1999) definition, the investments on financial products like debt securities, notes, money market instruments and financial derivatives in addition to equity securities are required to be considered in calculating FPI. However, the foreign investments made only on equity securities have been considered for this study.

The first explanatory variable, the All Share Price Index (ASPI) is the main index in which represents the price movements of all the listed shares at the CSE. ASPI is a market capitalization weighted index where the weight of any company is taken as the number of ordinary shares listed in the market. The movements of ASPI represent the performance of domestic stock market. The second explanatory variable, the Standard and Poor's 500 index (S\&P 500) is considered as the best representation of the American stock markets. The USA is the largest foreign portfolio investor in the world as well as in Sri Lanka. Thus, the S\&P 500 index is used to capture the 'Home Country Bias'. The third explanatory variable, foreign reserves in months of imports represent the creditworthiness of the host country and stability of local currency. A country with inadequate foreign reserves may face a potential risk of currency depreciation due to the controller's limited capability to maintain the stability by intervening in the currency market. As discussed, foreign portfolio investors concern the currency depreciation risk in decision making. Hence, the research uses the months of imports as an indicator of potential currency depreciation risk as well as of the creditworthiness of the country, from a foreign investor's point of view. The fourth explanatory variable, Treasury bill rate is considered as a short-term risk free rate in investment whilst it is also used as the benchmark for "the Risk free return" in calculating the expected return of an investment. Treasury bills are issued by the sovereign government and mature within maximum of one year. In this research paper, the three month Treasury 
bill rate is used as an indicator for the interest rate of the host country as well as an indicator of risk free return.

The fifth explanatory variable, the London Inter-Bank Offered Rates (LIBOR) is a globally accepted benchmark interest rate. The LIBOR represents the average interest rate of leading banks in London and is widely used as a reference rate for many financial instruments in both financial markets and in commerce. The sixth explanatory variable, the foreign currency exchange rate is the value of one currency for the purpose of conversion to another. Theoretically the exchange rate is determined by the demand and supply forces of a given currency as against others. However, in practice, exchange rate is determined by the exchange rate regime of the country. Sri Lanka reportedly adopted a flexible exchange rate policy in 2012 and publishes the exchange rates of main currencies it its website. Accordingly, the foreign currency exchange rate (LKR/ USD) published by the Central Bank of Sri Lanka (the average rate quoted by commercial banks in Colombo for Telegraphic Transfers (TT) ) is used in this research as an indicator of possible currency depreciation risk. The last explanatory variable, the Colombo Consumers' Price Index (CCPI) which is calculated by the Department of Census and Statistics of Sri Lanka is used to measure the inflation rate. The inflation premium of the risk free rate is determined on inflation rate. Thus, investors use inflation rate in calculating expected return and for the purpose of this research, the CCPI is used to reflect the inflation level of the economy.

Table 1 summarizes the descriptive statistics of 118 observations (two outliers out of 120 observations have been removed from analysis). The descriptive statistics describe the nature of the variables in consideration, using statistics which generalizes the data sample.

Table 1: Summary of Descriptive Statistics of the Given Variables

\begin{tabular}{lllllllll}
\hline & EFPI & LIBOR & MIMP & TBR & FOREX & CCPI & ASPI & SP500 \\
\hline Mean & 3923.10 & 2.09 & 3.80 & 10.68 & 112.14 & 192.91 & 3630.48 & 1273.15 \\
Median & 3496.24 & 1.16 & 3.40 & 9.41 & 110.44 & 205.55 & 2589.93 & 1270.15 \\
Maximum & 11479.95 & 5.51 & 6.40 & 21.30 & 132.87 & 275.60 & 7797.96 & 1848.36 \\
Minimum & 323.26 & 0.24 & 1.20 & 6.97 & 97.45 & 110.20 & 1211.10 & 735.09 \\
Std. Dev. & 2778.11 & 1.99 & 1.19 & 3.72 & 9.97 & 52.14 & 1952.00 & 208.41 \\
Skewness & 0.87 & 0.61 & 0.22 & 1.04 & 0.73 & -0.08 & 0.56 & 0.14 \\
Kurtosis & 3.00 & 1.76 & 2.73 & 2.81 & 2.57 & 1.69 & 1.79 & 3.28 \\
Observations & 118 & 118 & 118 & 118 & 118 & 118 & 118 & 118 \\
\hline
\end{tabular}

Table 2 shows the results of correlation analysis. According to results, the explanatory variables other than TBR and LIBOR have shown a positive correlation with EFPI in Sri Lanka. The ASPI, CCPI and MIMP indicate a strong positive correlation while FOREX and SP500 show a moderate positive correlation with EFPI. The LIBOR signifies a moderate negative correlation. TBR has no correlation or has a negligible negative correlation with the EFPI. The CCPI indicates a very strong correlation with both FOREX and ASPI which is a possible indication of multicollinearity. 
Table 2: The Results of Correlation Coefficient Estimates

\begin{tabular}{lllllllll}
\hline & EFPI & LIBOR & MIMP & TBR & FOREX & CCPI & ASPI & SP500 \\
\hline EFPI & 1 & & & & & & & \\
LIBOR & -0.330 & 1 & & & & & & \\
MIMP & 0.508 & -0.529 & 1 & & & & & \\
TBR & -0.168 & 0.538 & -0.580 & 1 & & & & \\
FOREX & 0.476 & -0.551 & 0.216 & -0.003 & 1 & & & \\
CCPI & 0.532 & -0.691 & 0.419 & -0.069 & 0.878 & 1 & & \\
ASPI & 0.579 & -0.618 & 0.678 & -0.392 & 0.631 & 0.819 & 1 & \\
SP500 & 0.304 & 0.131 & 0.217 & 0.073 & 0.461 & 0.331 & 0.428 & 1 \\
\hline
\end{tabular}

\section{Econometric Methodology}

Importantly, the analytical methods in the paper are mostly related to previous studies. The unit root test is useful in selecting the suitable method for analysis with particular attention to the given variables. The existence of a long-run relationship between the dependant variable and explanatory variables is tested by co-integration test. The causality test helps in figuring out the existence and direction of causality amongst variables in consideration. Short- run causality is determined by the joint significance of the lagged explanatory variables, using F- test.

The Autoregressive Distributed Lag (ARDL) model based on bounds test approach is applied to examine the co-integration relationship between EFPI and explanatory variables. The ARDL estimation crashes in the presence of integrated variables order higher than or equal to I(2). The unrestricted (Equation 2) and restricted (Equation 3) models are given below.

Equation 2: The Unrestricted Model

$$
\begin{aligned}
& E F P I_{t}=C_{0}+\sum_{i=0}^{p} C_{1 i} \operatorname{EFPI}_{t-i}+\sum_{i=0}^{p} C_{2 i} \operatorname{ASPI}_{t-i}+\sum_{i=0}^{p} C_{3 i} \operatorname{SP}^{2} 00_{t-i}+\sum_{i=0}^{p} C_{4 i} \operatorname{MIMP}_{t-i}+\sum_{i=0}^{p} C_{5 i} T_{B R}+ \\
& \sum_{i=0}^{p} C_{6 i} \text { LIBOR }_{t-i}+\sum_{i=0}^{p} C_{7 i} \text { FOREX }_{t-i}+\sum_{i=0}^{p} C_{8 i} \text { CCPI }_{t-i}+\theta_{0} \text { EFPI }_{t-1}+\theta_{1} \text { ASPI }_{t-1}+\theta_{2}{\text { SP } 500_{t-1}}+ \\
& \theta_{3} M_{I M P_{t-1}}+\theta_{4} \mathrm{TBR}_{t-1}+\theta_{5} \mathrm{LIBOR}_{t-1}+\theta_{6} \mathrm{FOREX}_{t-1}+\theta_{7} C C P I_{t-1}+e_{t}
\end{aligned}
$$

Equation 3: The Restricted Model

$$
\begin{aligned}
& \text { EFPI }_{t}=C_{0}+\sum_{i=0}^{p} C_{1 i} \text { EFPI }_{t-i}+\sum_{i=0}^{p} C_{2 i} \text { ASPI I }_{t-i}++\sum_{i=0}^{p} C_{3 i} \text { SP50O }_{t-i}+\sum_{i=0}^{p} C_{4 i} \text { MIMP }_{t-i}+\sum_{i=0}^{p} C_{5 i} \\
& \text { TBR }_{t-i}+\sum_{i=0}^{p} C_{6 i} \text { LIBOR }_{t-i}+\sum_{i=0}^{p} C_{7 i} \text { FOREX }_{t-i}+\sum_{i=0}^{p} C_{8 i} \text { CCPI }_{\mathrm{t}-\mathrm{i}}+\mathrm{e}_{\mathrm{t}}
\end{aligned}
$$

The lag length with the lowest value of Akaike Information Criteria (AIC) is considered as the optimal lag length. F-test statistic value is obtained by the unrestricted model equation in the bounds testing approach. The acceptance or rejection of the existence of a long-run relationship (cointegration) among the variables is tested using the F-test statistic of joint significance. The test for co-integration is carried out on the two asymptotic critical values (i.e., lower bound value and the upper bound value) of the Pesaran Table with reference to the given critical value (5 per cent) and the 
number of explanatory variables in consideration. Given the F- statistic of joint significance, if the existence of co-integration can be confirmed by bound testing, long-run coefficients are estimated using regression analysis. Pami and Reetika (2013) as well as Kaur and Dhillon (2010) had used the ARDL model and bounds testing approach in order to verify the long-run relationship using Fstatistic of joint significance. The long-run equation is given in equation 4 .

\section{Equation 4: The Long-run Equation}

$E F P I_{t}=\beta_{0}+\beta_{1} A S P I_{t}+\beta_{2}$ SP500 $_{t}+\beta_{3}$ MIMP $_{t}+\beta_{4} \mathrm{TBR}_{t}+\beta_{5} \mathrm{LIBOR}_{t}+\beta_{6} \mathrm{FOREX}_{t}+\beta_{7} C C P I_{t}+e_{t}$

Error correction model (ECM) is used to estimate both short-term and long-term effects of each time series on the other. The sign of the parameter associated with the error correction term is expected to be negative and accordingly the change in dependant variable would be negative to restore the equilibrium. How quickly the equilibrium is restored is denoted by the value of the parameter of the lagged error term. Then, the parameters associated with the long-run relationship which is represented by the error term is estimated on the basis of a long-run equation (Equation 4). The parameters of the short-run dynamics are estimated using the equation 5.

\section{Equation 5: Model for Short-run Dynamics}

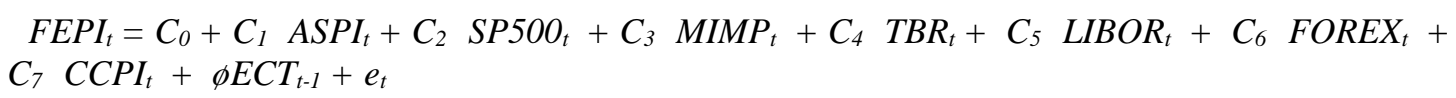

In equation 5, coefficients $\mathrm{C}_{1}, \mathrm{C}_{2}, \mathrm{C}_{3}, \mathrm{C}_{4}, \mathrm{C}_{5}, \mathrm{C}_{6}$ and $\mathrm{C}_{7}$ are the short-run dynamic coefficients. ECT stands for error correction term. The speed of adjustment represents the model's convergence toward equilibrium and it is denoted by $\emptyset$.

\section{Results}

The findings of Augmented Dickey Fuller (ADF) Unit root tests at level and at first difference are presented in tables 3 and 4 respectively. The results of ADF unit root test at level show that none of variables other than EFPI are stationary at level. In other words only EFPI is integrated at order I(0). However, the table 4 confirms that the remaining variables which are not integrated at level are stationary at first difference (integrated at order I(1)).

Thus, all the data series in the model are not integrated at the same order. Further, none of the variables are integrated above the order I(1). Therefore, the stationary test satisfies the pre-requisite for applying the ARDL model. Table 5 summarizes Akaike Information Criteria (AIC) values at different lag levels and the optimal lag length is determined using the lowest AIC. Accordingly, the perfect lag length is 10. F-statistic at the optimal lag length is calculated using the Wald Test and table 6 indicates the results. 
Table 3: The Results of Augmented Dickey Fuller Unit Root Test at Level

\begin{tabular}{|c|c|c|c|c|c|c|c|c|c|c|c|c|}
\hline \multirow[b]{2}{*}{$\begin{array}{l}\text { Level } \\
\text { Data }\end{array}$} & \multicolumn{4}{|c|}{ Intercept } & \multicolumn{4}{|c|}{ Trend \& Intercept } & \multicolumn{4}{|c|}{ None } \\
\hline & $\begin{array}{l}1 \% \\
\text { level }\end{array}$ & $\begin{array}{l}\text { t- } \\
\text { Statis } \\
\text { tic }\end{array}$ & Prob & $\begin{array}{l}\text { Coeff } \\
\text { icient }\end{array}$ & $\begin{array}{l}1 \% \\
\text { level }\end{array}$ & $\begin{array}{l}\text { t- } \\
\text { Statis } \\
\text { tic }\end{array}$ & Prob & $\begin{array}{l}\text { Coeff } \\
\text { icient }\end{array}$ & $\begin{array}{l}1 \% \\
\text { level }\end{array}$ & $\begin{array}{l}\text { t- } \\
\text { Statis } \\
\text { tic }\end{array}$ & Prob & $\begin{array}{l}\text { Coeff } \\
\text { icient }\end{array}$ \\
\hline EFPI & -3.488 & -2.919 & 0.046 & -0.255 & -4.038 & -7.235 & 0.000 & -0.634 & -2.585 & -1.191 & 0.213 & -0.054 \\
\hline LIBOR & -3.487 & -0.480 & 0.890 & -0.006 & -4.038 & -2.242 & 0.462 & -0.036 & -2.585 & -0.560 & 0.473 & -0.005 \\
\hline MIMP & -3.488 & -2.210 & 0.204 & -0.050 & -4.039 & -2.695 & 0.241 & -0.068 & -2.585 & -0.463 & 0.513 & -0.003 \\
\hline TBR & -3.489 & -1.641 & 0.459 & -0.029 & -4.041 & -1.776 & 0.710 & -0.031 & -2.585 & -0.616 & 0.449 & -0.003 \\
\hline FOREX & -3.488 & -0.971 & 0.762 & -0.013 & -4.039 & -2.759 & 0.216 & -0.079 & -2.585 & 1.140 & 0.934 & 0.001 \\
\hline CCPI & -3.488 & -0.461 & 0.894 & -0.001 & -4.039 & -2.283 & 0.440 & -0.052 & -2.585 & 3.676 & 1.000 & 0.004 \\
\hline ASPI & -3.487 & -0.802 & 0.815 & -0.010 & -4.038 & -1.415 & 0.852 & -0.035 & -2.585 & 1.032 & 0.920 & 0.006 \\
\hline SP500 & -3.487 & 0.087 & 0.964 & 0.002 & -4.038 & -0.434 & 0.985 & -0.011 & -2.585 & 1.314 & 0.952 & 0.005 \\
\hline
\end{tabular}

Table 4: The Results of Augmented Dickey Fuller Unit Root Test at First Difference

\begin{tabular}{|c|c|c|c|c|c|c|c|c|c|c|c|c|}
\hline \multirow{2}{*}{$\begin{array}{l}\text { First } \\
\text { Differe } \\
\text { nce }\end{array}$} & \multicolumn{4}{|c|}{ Intercept } & \multicolumn{4}{|c|}{ Trend \& Intercept } & \multicolumn{4}{|c|}{ None } \\
\hline & $\begin{array}{l}1 \% \\
\text { level }\end{array}$ & $\begin{array}{l}\mathrm{t}- \\
\text { Statis } \\
\text { tic }\end{array}$ & Prob & $\begin{array}{l}\text { Coeff } \\
\text { icient }\end{array}$ & $\begin{array}{l}1 \% \\
\text { level }\end{array}$ & $\begin{array}{l}\text { t- } \\
\text { Statis } \\
\text { tic }\end{array}$ & Prob & $\begin{array}{l}\text { Coeff } \\
\text { icient }\end{array}$ & $\begin{array}{l}1 \% \\
\text { level }\end{array}$ & $\begin{array}{l}\mathrm{t}- \\
\text { Statis } \\
\text { tic }\end{array}$ & Prob & $\begin{array}{l}\text { Coef } \\
\text { ficie } \\
\text { nt }\end{array}$ \\
\hline EFPI & -3.488 & -12.56 & 0.000 & -1.910 & -4.040 & -12.52 & 0.000 & -1.912 & -2.585 & -12.61 & 0.000 & -1.909 \\
\hline LIBOR & -3.488 & -8.532 & 0.000 & -0.779 & -4.039 & -8.685 & 0.000 & -0.801 & -2.585 & -8.563 & 0.000 & -0.779 \\
\hline MIMP & -3.488 & -6.785 & 0.000 & -0.577 & -4.039 & -6.771 & 0.000 & -0.578 & -2.585 & -6.812 & 0.000 & -0.577 \\
\hline TBR & -3.489 & -3.902 & 0.003 & -0.565 & -4.041 & -4.002 & 0.011 & -0.591 & -2.585 & -3.921 & 0.000 & -0.566 \\
\hline FOREX & -3.488 & -7.097 & 0.000 & -0.613 & -4.039 & -7.077 & 0.000 & -0.614 & -2.585 & -6.974 & 0.000 & -0.594 \\
\hline CCPI & -3.488 & -6.711 & 0.000 & -0.567 & -4.039 & -6.680 & 0.000 & -0.567 & -2.585 & -4.997 & 0.000 & -0.357 \\
\hline ASPI & -3.488 & -9.481 & 0.000 & -0.882 & -4.039 & -9.440 & 0.000 & -0.882 & -2.585 & -9.335 & 0.000 & -0.863 \\
\hline SP500 & -3.488 & -9.125 & 0.000 & -0.846 & -4.039 & -9.231 & 0.000 & -0.860 & -2.585 & -9.050 & 0.000 & -0.835 \\
\hline
\end{tabular}

Table 5: The Results of Akaike Information Criteria (AIC) in Different Periods

\begin{tabular}{lccccccccccc}
\hline Lag Level & $\mathbf{1}$ & $\mathbf{2}$ & $\mathbf{3}$ & $\mathbf{4}$ & $\mathbf{5}$ & $\mathbf{6}$ & $\mathbf{7}$ & $\mathbf{8}$ & $\mathbf{9}$ & $\mathbf{1 0}$ & $\mathbf{1 1}$ \\
\hline $\begin{array}{l}\text { Akaike } \\
\text { info } \\
\text { criterion }\end{array}$ & 18.25 & 18.30 & 18.38 & 18.40 & 18.47 & 18.42 & 18.34 & 18.25 & 18.15 & 17.51 & N/A \\
\hline
\end{tabular}

Table 6: The Result of Wald Test

\begin{tabular}{cccc}
\hline Test Statistic & Value & df & Probability \\
\hline F-statistic & 5.120279 & $(8,18)$ & 0.0019 \\
Chi-square & 40.96223 & 8 & 0.0000 \\
\hline
\end{tabular}


R-squared value of 0.939004 and 0.800197 of unrestricted and restricted model (see appendices) respectively, indicate that a 93.90 per cent and 80.01 per cent variation in EFPI can be jointly explained by the explanatory variables in the respective model. The remaining 6.10 per cent and 19.99 per cent can be explained by residuals or other variables of the respective model.

Having established that a long-run relationship exists ${ }^{1}$, parameters of the long-run coefficients are calculated using Ordinary Least Squares (OLS) method. Summary results of the regression analysis are given in the table 7.

Table 7: The Result of the Regression Analysis- Long Run Model

\begin{tabular}{lllllllll}
\hline Variable & C & LIBOR & MIMP & TBR & FOREX & CCPI & ASPI & SP500 \\
\hline Coefficient & -15423.62 & 506.95 & 1106.84 & 25.11 & 141.90 & -1.25 & 0.39 & -2.58 \\
Std. Error & 4429.15 & 255.02 & 275.86 & 106.64 & 57.50 & 17.60 & 0.31 & 1.62 \\
t-Statistic & $-3.482 * * *$ & $1.988^{* *}$ & $4.012 * * *$ & 0.235 & $2.468 * *$ & -0.071 & 1.28 & -1.59 \\
\hline R-squared & & 0.4461 & & & F-statistic & 12.657 \\
Durbin-Watson stat & 1.583 & & & Prob (F-statistic) & 0.000 \\
\hline
\end{tabular}

Notes: *** and ** indicate significance at the 1 and $5 \%$ level respectively

$\mathrm{EFPI}=-15423.62+506.953 \mathrm{LIBOR}+1106.837 \mathrm{MIMP}+25.107 \mathrm{TBR}$

+141.902 FOREX - 1.249 CCPI+ 0.393 ASPI- 2.577 SP500+ $\mathrm{e}_{\mathrm{t}}$

The regression results suggest that three explanatory variables, LIBOR, MIMP, and FOREX are statistically significant in determining EFPI in Sri Lanka. Furthermore, the remaining variables ASPI, TBR, CCPI and SP500 are statistically insignificant.

As per the results, the expected sign of the parameters associated with the explanatory variables other than LIBOR and FOREX are consistent with the conceptual model. LIBOR and FOREX have shown a positive relationship towards EFPI although a negative relationship is expected as per the conceptual model. R-squared value of 0.4461 indicates that a 44.61 per cent variation in EFPI can be jointly explained by the seven explanatory variables in consideration. The remaining 55.39 per cent can be explained by residuals or other variables. The model is not spurious (or not a nonsense model) since R- squared value of 0.4461 is less than the Durbin-Watson statistic of 1.583. The F-statistic with a strong probability value also confirms the same findings and indicates that the model has a very good fit. Accordingly, the explanatory variables in the model can jointly influence EFPI.

The Breusch-Godfrey Serial Correlation LM Test is applied to observe the autocorrelation and the table 8 summarizes the results of the same. The test confirms that the model is free from serial correlation (or problem of autocorrelation). The CUSUM test too certifies that the model is stable as the CUSUM line does not touch lower and upper 5 per cent significant lines (see figure 2). Heteroscedasticity is tested by 'White Heteroskedasticity Test' (table 9). The p-value of Observed Rsquared confirms that residuals do have constant variance which is desirable (residuals are homoscedastic). The results of Histogram-Normality test explain that population's residuals (u) are not normally distributed since $\mathrm{p}$ value is less than 5 percent (figure 3 ).

\footnotetext{
${ }^{1}$ The lower bound value and upper bound value are extracted from the Pesaran table (unrestricted intercept and no trend) at 5 per cent level of significance. The estimated F-statistic (5.120279) exceeds the upper bound value (upper bound value: 3.553). Thus, it can be concluded that a long-run co-integration relationship exists among the variables.
} 
Table 8: The Results of the Breusch-Godfrey Serial Correlation LM Test for Long-run Model

\begin{tabular}{lcc}
\hline & Value & Probability \\
\hline F-statistic & 1.316606 & 0.231979 \\
Obs*R-squared & 13.72845 & 0.185742 \\
\hline
\end{tabular}

Figure 2: CUSUM Test Graph for Long Run Model

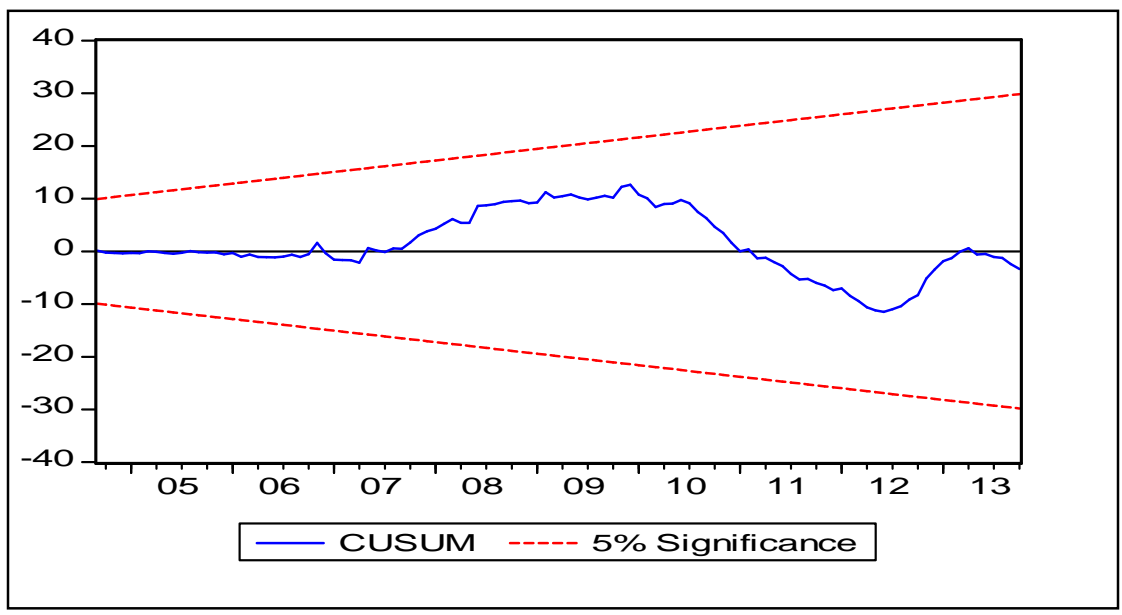

Table 9: The Results of the White Heteroskedasticity Test for Long-run Model

\begin{tabular}{lcc}
\hline & Value & Probability \\
\hline F-statistic & 0.786988 & 0.680954 \\
Obs*R-squared & 11.40264 & 0.654156 \\
\hline
\end{tabular}

Figure 3: The Result of Histogram-Normality Test for Long Run Model

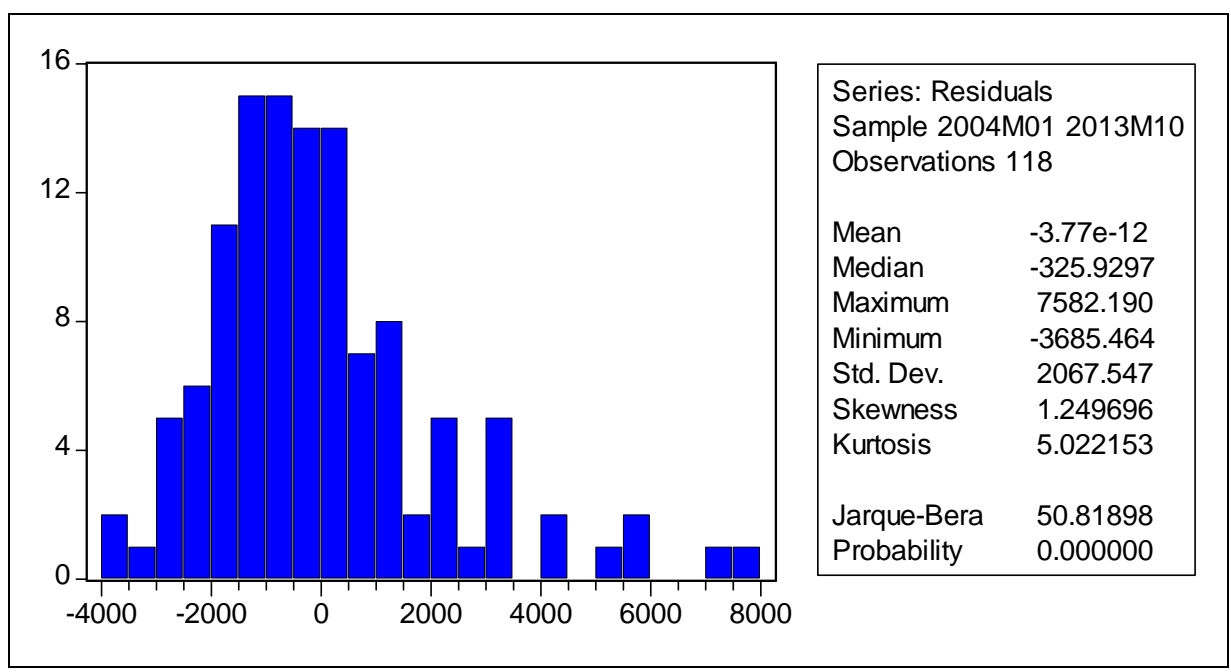


The table 10 reports the short-run coefficient and error correction term of the model. The sign of the coefficient of Error Correction Term U(-1) is negative (-0.82) as anticipated, and it is very significant (Prob. 0.0000). The error correction term guides the variables of the model to restore back to equilibrium from a previous period's disequilibrium. Thus, it validates that a long-term relationship exists among variables in the original model.

Table 10: The Short Run Coefficient and Error Correction Term

\begin{tabular}{llllllllll}
\hline Variable & C & D(LIBOR) & D(MIMP) & D(TBR) & D(FOREX) & D(CCPI) & D(ASPI) & D(SP500) & ECT(-1) \\
\hline Coefficient & -45.11 & 493.42 & 295.03 & -30.48 & 98.99 & -17.36 & 1.75 & 2.50 & -0.82 \\
Std. Error & 244.15 & 761.51 & 636.56 & 277.83 & 126.99 & 104.03 & 0.75 & 4.14 & 0.09 \\
t-Statistic & -0.185 & 0.648 & 0.463 & -0.110 & 0.780 & -0.167 & $2.334 *$ & 0.605 & $-8.74 * *$ \\
\hline R-squared & & 0.429 & & F-statistic & 10.130 & & \\
Durbin-Watson stat & 2.118 & & Prob (F-statistic) & 0.000 & & \\
\hline
\end{tabular}

Notes: ** and * indicate significance at the 1 and 5\% level respectively

Thus, if the dependant variable is above its equilibrium value, it will start falling in the next period in order to correct the equilibrium error. The monthly speed at which ECT is correcting the disequilibrium is 82 per cent. Put in other words, it is adjusting the previous period's disequilibrium at the rate of 82 per cent. Further, R-squared value which is less than Durbin-Watson statistics value indicates that the model is not spurious. The Breusch-Godfrey Serial Correlation LM Test confirms that ECM is not serially correlated (table 11). The CUSUM test too certifies that the error correction model is stable (figure 4).

Table 11: The Results of the Breusch-Godfrey Serial Correlation LM Test for Error Correction Model

\begin{tabular}{lcc}
\hline & Value & Probability \\
\hline F-statistic & 1.406332 & 0.188749 \\
Obs*R-squared & 14.68285 & 0.14406 \\
\hline
\end{tabular}

\section{Figure 4: CUSUM Test Graph for Error Correction Model}

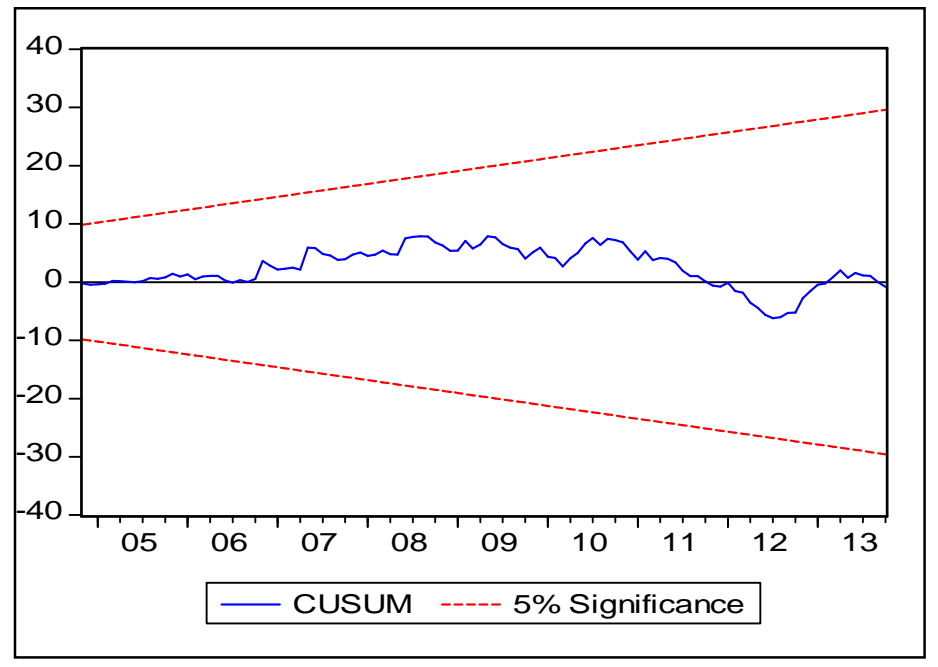


Causality framework has evolved to become a standard statistical technique to uncover causal relationships between variables. It explains the short-run causality running from an independent variable to a dependent variable. The existence of causality is tested using Wald Test and the table12 summarizes the results. The findings of the causality test confirm that the MIMP, TBR, FOREX and CCPI show a statistically significant causal relationship at different levels of significance. Thus, the lag values of the said variables can jointly impact the dependant variable. Therefore, it can be concluded that there is a short-run causality running from MIMP, TBR, FOREX and CCPI towards EFPI in Sri Lanka.

Table 12: Summary of Wald Tests

\begin{tabular}{llllllll}
\hline Variable & LIBOR & MIMP & TBR & FOREX & CCPI & ASPI & SP500 \\
\hline F-statistic & 1.414 & 2.959 & 2.044 & 2.378 & 1.782 & 1.203 & 1.495 \\
Causality & No & Yes*** & Yes** & Yes*** & Yes* & No & No \\
\hline
\end{tabular}

Notes: $* * *, * *$ and $*$ indicate significance at the 1,5 and $10 \%$ level respectively

\section{Discussion of Findings}

The findings confirm that there is a long-run co-integration relationship between the variables. Thus, the following key findings are observed for the period which covers the decade that lasted up to 2013.There is a statistically significant long-run positive relationship with LIBOR, MIMP, TBR, FOREX and ASPI towards EFPI in Sri Lanka. CCPI and SP500 report a negative relationship. Although a negative relationship is anticipated in the conceptual model, LIBOR shows a positive relationship. The causality test confirms a short-run causality running from LIBOR towards EFPI in Sri Lanka.

A statistically significant long-run positive relationship is observed between foreign reserve position in months of imports and EFPI in Sri Lanka. The observed relationship is in line with the previous research finding and theoretical explanations. A strong foreign reserve position indicates the regulator's capability on ensuring stability of the currency and the creditworthiness of the country which consequently encourages EFPI. Thus, a strong foreign reserve position is critical in attracting EFPI in Sri Lanka. Moreover, the findings also confirm a short-run causality running from months of imports towards EFPI in Sri Lanka.

A statistically significant long-run positive relationship is detected between LKR/ USD exchange rate and EFPI in Sri Lanka. The finding is contradictory with theory as literature says that depreciation in local currency discourages FPI. Further, causality test confirms a short-run causality running from LKR/USD exchange rate towards EFPI.

The ASPI which represents the domestic capital market performance reports a positive effect towards EFPI as anticipated, although the coefficient value is statistically insignificant. The healthy domestic market performance is critical in attracting EFPI.

As the main investing country in the CSE, the performance of the US's main index could affect cross broader investment decision due to 'Home Country Bias'. Despite the result being statistically insignificant, the fact that foreign investors tend to invest domestically when the domestic market 
performs well is consistent with the research findings. Further, no short-run causality is witnessed running from S\&P 500 index towards EFPI.

A statistically insignificant long-run positive relationship is noticed between three months Treasury bill rates and EFPI in Sri Lanka. Investors generally consider changes in Treasury bill rates as the basis for calculating most asset returns in an economy. The rising Treasury bill rates in an economy may indicate better returns on investment. Further, the causality test confirms a short-run causality running from three months Treasury bill rates towards EFPI. Thus, three months Treasury bill rate is a stimulus for EFPI in Sri Lanka.

Despite the fact that the CCPI indicates a negative relationship as anticipated in the conceptual model, the coefficient value is statistically insignificant. The tests confirm a short run causality running from CCPI towards EFPI in Sri Lanka.

\section{Conclusion}

The historical data indicates that the EFPI plays a significant role in the CSE, thereby enhancing market liquidity as well as efficiency and provides incentives for corporate governance and best practices. Literature in the field documents that besides the domestic macroeconomic variables of the host country, the global variables and the macroeconomic variables in the source country affect FPI in the host country. Empirical evidence provides inconsistent relationships between explanatory variables and EFPI indicating that the relationship is identical to the country in consideration. Some research findings are not in line with the theoretical explanations. Therefore, identifying the determinants of EFPI in Sri Lanka is important for policy makers and market intermediaries. Thus, the main objective of this research is to identify the long-run effect of the selected explanatory variables on EFPI in Sri Lanka. The research uses ten years' monthly data from January 2004 to December 2013 to analyze the effect of explanatory variables on EFPI. Accordingly, LIBOR, months of imports, USD/ LKR exchange rate and ASPI are found to be statistically significant and to have a long-run positive effect on EFPI in Sri Lanka. The remaining explanatory variables (S\&P500 index, threemonth Treasury bill rates and CCPI) are statistically insignificant. It is further revealed that there is a short-run causality running from months of imports, three-month Treasury bill rates, USD/LKRexchange rates and CCPI towards EFPI in the CSE.

\section{Policy Implications}

Most of the global factors considered in this research are beyond Sri Lanka's control given its status as a relatively small nation in terms of GDP and global financial market participation. However, domestic factors which are within the control of policy makers can be used to attract EFPI to Sri Lanka. Indeed, maintaining a strong foreign reserve position is critical in demonstrating the rupee's stability, particularly to attract foreign portfolio investments.

\section{References}

Agarwal, R. N. (1997). Foreign portfolio investment in some developing countries: A study of determinants and macroeconomic impact. Indian Economic Review, 32(2), 217-229.

Bartram, S. M., \& Dufey, G. (2001). International portfolio investment: Theory, evidence, and institutional framework. [Reader version]. Retrieved from http://papers.ssrn.com/sol3/papers.cfm? abstract_id=270196 
Benson, J. D. (2003). Foreign portfolio investment, foreign bank lending, and economic growth (International Finance Discussion Papers No. 757). Retrieved from Federal Reserve System website: http://www.federalreserve.gov/pubs/ifdp/2003/757/ifdp757.pdf

Bryan, D. C., \& Debbie, F. (1990). The guide to investing in emerging securities markets. London, England: Euromoney Books Publishing.

Central Bank of Sri Lanka. Annual Report. Colombo: Author (Various Issues)

Colombo Stock Exchange. Annual Report. Colombo: Author (Various Issues)

Duasa, J., \& Kassim, S. H. (2009). Foreign portfolio investment and economic growth in Malaysia. The Pakistan Development Review, 48(2), 109-123. Retrieved from Pakistan Institute of Development Economics website: http://pide.org.pk/pdr/index.php/pdr/article/viewFile/ 2613/2585

Ekeocha, P. C., Malaolu, C. S., Oduh, V., \& Onyema, M. (2012). Modeling the long run determinants of foreign portfolio investment in Nigeria. Journal of Economics and Sustainable Development, $3(8)$, 194-205. Retrieved from http://pakacademicsearch.com/pdf-files/ech/520/194$205 \% 20 \mathrm{Vol} \% 203, \% 20 \mathrm{No} \% 208 \% 20(2012)$.pdf

Evans, K. (2002, December). Foreign porffolio and direct investment- complementarity, differences, and integration. Retrieved from Organisation for Economic Co-operation and Development website http://www.oecd.org/investment/investmentfordevelopment/ 2764407.pdf

Fernandez-Arias, E., \& Montiel, P. J. (1995). The surge in capital inflows to developing countries: Prospects and policy response (The World Bank Policy Working Paper No. 1473). Retrieved from https://core.ac.uk/

Gumus, G. K., Duru, A., \& Gungor, B. (2013). The relationship between foreign portfolio investment and macroeconomic variables. European Scientific Journal, 9(34), 209-226. Retrieved from http://eujournal.org/index.php/esj/article/viewFile/2171/2056

Kaur, M., \& Dhillon, S. S. (2010). Determinants of foreign institutional investors' investment in India. Eurasian Journal of Business and Economics, 3(6), 57-70. Retrieved from http://ejbe.org/EJBE2010Vo103No06p57KAUR-DHILLON.pdf

Kim, H. M. (1999). Globalization of international financial markets: Causes and consequences. Aldershot, UK: Ashgate.

Kim, S., Kim, S., \& Choi, Y. (2013). Determinants of international capital flows in Korea: Push vs. pull factors. Korea and the World Economy, 14(3), 447-474. Retrieved from The Association of Korean Economic Studies website: http://www.akes.or.kr/akes/downfile/14.3.2\%20 Kim_Kim_Choi\%20(447-474).pdf

Parthapratim, P. (2011). Foreign portfolio investment, stock market and economic development: A case study of India. Paper presented at the Annual Conference on Development and Change Mission: Promoting Development in a Globalized World, Sao Paulo, Brazil. Retrieved from http://www.policyinnovations.org/

Pami, D., \& Reetika, G. (2013). Foreign portfolio investment flows to India: Determinants and analysis (Centre for Development Economics of Delhi School of Economics Working Papers No. 225). Retrieved from Centre for Development Economics website: http://www.cdedse.org/pdf/work225.pdf

Sakuragawa, M., \& Watanabe, Y. (2010). Foreign direct and portfolio investments in the world (Global Security Research Institute of Keio University Working Papers No. 28). Retrieved from Global Security Research Institute website: https://www1.gsec.keio.ac.jp/imgdata/working/ 30_pdf.pdf 
Sharan, V. (2005). International financial management ( $3^{\text {rd }}$ ed.). Cengage Learning Publishing.

Secretariat of United Nations Conference on Trade and Development. (1999). Comprehensive study of the interrelationship between foreign direct investment (FDI) and foreign portfolio investment (FPI), (United Nations Conference on Trade and Development Staff Paper No. UNCTAD/GDS/DFSB/5). Retrieved from United Nations Conference on Trade and Development website: http://unctad.org/en/Docs/pogdsdfsbd5.pdf

\section{Appendices}

\section{Appendix 1: Unrestricted Model}

\begin{tabular}{|c|c|c|c|c|}
\hline $\begin{array}{l}\text { Dependent Var } \\
\text { Method: Least } \\
\text { Date: 01/14/16 } \\
\text { Sample (adjust } \\
\text { Included obser }\end{array}$ & $\begin{array}{l}07 \\
712 \text { 2013M10 } \\
7 \text { after adjust }\end{array}$ & ments & & \\
\hline Variable & Coefficient & Std. Error & t-Statistic & Prob. \\
\hline C & -99967.93 & 32956.63 & -3.033318 & 0.0071 \\
\hline D(FEPI(-1)) & 3.645724 & 1.381308 & 2.639327 & 0.0167 \\
\hline D(FEPI $(-2))$ & 3.004249 & 1.201513 & 2.500388 & 0.0223 \\
\hline D(FEPI(-3)) & 2.316145 & 1.064266 & 2.176284 & 0.0431 \\
\hline D(FEPI(-4)) & 2.078862 & 0.892935 & 2.328122 & 0.0318 \\
\hline D(FEPI $(-5))$ & 1.837363 & 0.765165 & 2.401264 & 0.0274 \\
\hline D(FEPI(-6)) & 1.495924 & 0.603874 & 2.477213 & 0.0234 \\
\hline D(FEPI(-7)) & 1.208211 & 0.435927 & 2.771591 & 0.0126 \\
\hline D(FEPI(-8)) & 0.765783 & 0.300011 & 2.552521 & 0.0200 \\
\hline D(FEPI(-9)) & 0.699356 & 0.215515 & 3.245049 & 0.0045 \\
\hline D(FEPI(-10)) & 0.646777 & 0.158146 & 4.089745 & 0.0007 \\
\hline D(ASPI(-1)) & 0.920232 & 1.924379 & 0.478197 & 0.6383 \\
\hline D(ASPI(-2)) & 3.708137 & 2.195750 & 1.688779 & 0.1085 \\
\hline D(ASPI(-3)) & 5.632534 & 2.505589 & 2.247988 & 0.0373 \\
\hline D(ASPI(-4)) & 4.820106 & 3.047858 & 1.581473 & 0.1312 \\
\hline D(ASPI(-5)) & 4.186957 & 2.883334 & 1.452123 & 0.1637 \\
\hline D(ASPI(-6)) & 2.890674 & 2.871113 & 1.006813 & 0.3274 \\
\hline D(ASPI(-7)) & 2.521001 & 2.763273 & 0.912324 & 0.3737 \\
\hline D(ASPI(-8)) & 1.949699 & 2.421712 & 0.805091 & 0.4313 \\
\hline D(ASPI(-9)) & 3.820297 & 2.038947 & 1.873662 & 0.0773 \\
\hline D(ASPI(-10)) & 0.292041 & 1.861515 & 0.156883 & 0.8771 \\
\hline D(SP500(-1)) & 22.03251 & 13.09484 & 1.682534 & 0.1097 \\
\hline D(SP500(-2)) & 34.76036 & 13.22185 & 2.629008 & 0.0170 \\
\hline $\mathrm{D}(\mathrm{SP} 500(-3))$ & 37.02011 & 16.07056 & 2.303598 & 0.0334 \\
\hline D(SP500(-4)) & 38.05288 & 16.77473 & 2.268465 & 0.0358 \\
\hline D(SP500(-5)) & 32.99585 & 13.00341 & 2.537478 & 0.0206 \\
\hline D(SP500(-6)) & 20.64767 & 13.32991 & 1.548973 & 0.1388 \\
\hline D(SP500(-7)) & 6.115694 & 12.28661 & 0.497753 & 0.6247 \\
\hline
\end{tabular}


G. D. K. Kumara \& D. A. I. Dayaratne / Colombo Business Journal, 6/2

\begin{tabular}{|c|c|c|c|c|}
\hline D(SP500(-8)) & 18.79030 & 10.88084 & 1.726916 & 0.1013 \\
\hline D(SP500(-9)) & 6.811787 & 10.90943 & 0.624394 & 0.5402 \\
\hline $\mathrm{D}(\operatorname{SP} 500(-10))$ & -1.741892 & 10.35087 & -0.168285 & 0.8682 \\
\hline D(MIMP(-1)) & -8057.367 & 2805.291 & -2.872203 & 0.0101 \\
\hline $\mathrm{D}(\mathrm{MIMP}(-2))$ & -6132.491 & 2429.212 & -2.524478 & 0.0212 \\
\hline D(MIMP(-3)) & -7690.070 & 2884.921 & -2.665608 & 0.0158 \\
\hline D(MIMP(-4)) & -5336.098 & 2082.340 & -2.562549 & 0.0196 \\
\hline D(MIMP(-5)) & -4108.070 & 2043.330 & -2.010479 & 0.0596 \\
\hline D(MIMP(-6)) & -2623.877 & 1267.705 & -2.069785 & 0.0531 \\
\hline D(MIMP(-7)) & -5076.167 & 1824.461 & -2.782283 & 0.0123 \\
\hline D(MIMP(-8)) & -6973.836 & 1935.594 & -3.602944 & 0.0020 \\
\hline D(MIMP(-9)) & -1750.557 & 1801.164 & -0.971904 & 0.3440 \\
\hline D(MIMP(-10)) & -1569.108 & 2149.465 & -0.729999 & 0.4748 \\
\hline $\mathrm{D}(\mathrm{TBR}(-1))$ & 302.3920 & 1035.156 & 0.292122 & 0.7735 \\
\hline $\mathrm{D}(\mathrm{TBR}(-2))$ & -561.0311 & 777.3894 & -0.721686 & 0.4798 \\
\hline $\mathrm{D}(\mathrm{TBR}(-3))$ & 23.23772 & 689.1109 & 0.033721 & 0.9735 \\
\hline $\mathrm{D}(\mathrm{TBR}(-4))$ & 1121.911 & 718.4572 & 1.561556 & 0.1358 \\
\hline $\mathrm{D}(\mathrm{TBR}(-5))$ & 56.25130 & 832.6621 & 0.067556 & 0.9469 \\
\hline $\mathrm{D}(\mathrm{TBR}(-6))$ & 1674.034 & 926.4459 & 1.806942 & 0.0875 \\
\hline $\mathrm{D}(\mathrm{TBR}(-7))$ & 1644.836 & 826.5708 & 1.989952 & 0.0620 \\
\hline $\mathrm{D}(\mathrm{TBR}(-8))$ & 1140.557 & 797.0891 & 1.430903 & 0.1696 \\
\hline $\mathrm{D}(\mathrm{TBR}(-9))$ & 326.2248 & 635.8406 & 0.513061 & 0.6141 \\
\hline $\mathrm{D}(\mathrm{TBR}(-10))$ & 422.7328 & 885.9468 & 0.477154 & 0.6390 \\
\hline $\mathrm{D}(\mathrm{LIBOR}(-1))$ & -3547.694 & 2844.292 & -1.247303 & 0.2283 \\
\hline $\mathrm{D}(\mathrm{LIBOR}(-2))$ & -1025.857 & 2640.393 & -0.388524 & 0.7022 \\
\hline D(LIBOR(-3)) & -3637.189 & 2396.527 & -1.517692 & 0.1465 \\
\hline D(LIBOR(-4)) & -5234.190 & 2275.109 & -2.300632 & 0.0336 \\
\hline $\mathrm{D}(\mathrm{LIBOR}(-5))$ & -48.71474 & 2365.931 & -0.020590 & 0.9838 \\
\hline $\mathrm{D}(\mathrm{LIBOR}(-6))$ & -806.6137 & 2157.128 & -0.373929 & 0.7128 \\
\hline $\mathrm{D}(\mathrm{LIBOR}(-7))$ & -3485.660 & 2355.916 & -1.479535 & 0.1563 \\
\hline $\mathrm{D}(\mathrm{LIBOR}(-8))$ & -1194.133 & 1896.608 & -0.629615 & 0.5369 \\
\hline D(LIBOR(-9)) & 590.8312 & 1855.896 & 0.318354 & 0.7539 \\
\hline D(LIBOR(-10)) & -2008.380 & 1830.438 & -1.097213 & 0.2870 \\
\hline $\mathrm{D}(\mathrm{FOREX}(-1))$ & -79.33373 & 501.4391 & -0.158212 & 0.8761 \\
\hline $\mathrm{D}(\operatorname{FOREX}(-2))$ & -945.3437 & 463.3824 & -2.040094 & 0.0563 \\
\hline D(FOREX $(-3))$ & -668.5860 & 434.2919 & -1.539486 & 0.1411 \\
\hline $\mathrm{D}(\mathrm{FOREX}(-4))$ & -883.5985 & 409.9209 & -2.155534 & 0.0449 \\
\hline D(FOREX $(-5))$ & -910.9150 & 397.5310 & -2.291431 & 0.0342 \\
\hline $\mathrm{D}(\mathrm{FOREX}(-6))$ & -464.3989 & 352.1087 & -1.318908 & 0.2037 \\
\hline $\mathrm{D}(\mathrm{FOREX}(-7))$ & -129.8356 & 400.5500 & -0.324143 & 0.7496 \\
\hline D(FOREX $(-8))$ & -458.4177 & 387.7786 & -1.182163 & 0.2525 \\
\hline $\mathrm{D}(\mathrm{FOREX}(-9))$ & -322.6175 & 306.2752 & -1.053358 & 0.3061 \\
\hline D(FOREX(-10)) & -1057.339 & 331.4698 & -3.189850 & 0.0051 \\
\hline $\mathrm{D}(\mathrm{CCPI}(-1))$ & -21.05762 & 314.4346 & -0.066970 & 0.9473 \\
\hline $\mathrm{D}(\mathrm{CCPI}(-2))$ & -561.5784 & 321.3901 & -1.747342 & 0.0976 \\
\hline D(CCPI(-3)) & -362.3673 & 311.5859 & -1.162977 & 0.2600 \\
\hline D(CCPI(-4)) & -635.3770 & 303.9959 & -2.090084 & 0.0511 \\
\hline $\mathrm{D}(\mathrm{CCPI}(-5))$ & -197.5877 & 309.5925 & -0.638219 & 0.5314 \\
\hline $\mathrm{D}(\mathrm{CCPI}(-6))$ & -343.2495 & 319.6087 & -1.073968 & 0.2970 \\
\hline $\mathrm{D}(\mathrm{CCPI}(-7))$ & -513.6649 & 364.5345 & -1.409098 & 0.1758 \\
\hline
\end{tabular}


G. D. K. Kumara \& D. A. I. Dayaratne / Colombo Business Journal, 6/2

\begin{tabular}{|lllll|}
\hline D(CCPI(-8)) & 185.9059 & 319.9341 & 0.581076 & 0.5684 \\
D(CCPI(-9)) & 711.9692 & 297.8645 & 2.390245 & 0.0280 \\
D(CCPI(-10) & -60.48079 & 317.3626 & -0.190573 & 0.8510 \\
FEPI(-1) & -5.194367 & 1.483370 & -3.501734 & 0.0025 \\
ASPI(-1) & -4.183583 & 2.190447 & -1.909922 & 0.0722 \\
SP500(-1) & -7.507987 & 10.28981 & -0.729653 & 0.4750 \\
MIMP(-1) & 8131.536 & 2629.236 & 3.092738 & 0.0063 \\
TBR(-1) & -134.8687 & 784.5688 & -0.171902 & 0.8654 \\
LIBOR(-1) & 3080.286 & 891.1010 & 3.456719 & 0.0028 \\
FOREX(-1) & 669.1859 & 432.8765 & 1.545905 & 0.1395 \\
CCPI(-1) & 184.1250 & 130.8053 & 1.407626 & 0.1763 \\
\hline \hline R-squared & 0.939004 & Mean dependent var & 32.50234 \\
Adjusted R-squared & 0.640802 & S.D. dependent var & 2715.411 \\
S.E. of regression & 1627.432 & Akaike info criterion & 17.50849 \\
Sum squared resid & 47673617 & Schwarz criterion & 19.73168 \\
Log likelihood & -847.7041 & F-statistic & 3.148881 \\
Durbin-Watson stat & 2.299596 & Prob(F-statistic) & 0.003928 \\
\hline \hline
\end{tabular}

\section{Appendix 2: Restricted model}

Dependent Variable: D(FEPI)

Method: Least Squares

Date: 01/14/16 Time: 02:11

Sample (adjusted): 2004M12 2013M10

Included observations: 107 after adjustments

\begin{tabular}{|lllll|}
\hline Variable & Coefficient & Std. Error & t-Statistic & Prob. \\
\hline \hline C & 438.0719 & 1315.815 & 0.332928 & 0.7419 \\
D(FEPI(-1)) & -0.625932 & 0.233703 & -2.678318 & 0.0127 \\
D(FEPI(-2)) & -0.544876 & 0.283432 & -1.922424 & 0.0656 \\
D(FEPI(-3)) & -0.558773 & 0.301431 & -1.853735 & 0.0752 \\
D(FEPI(-4)) & -0.266335 & 0.306757 & -0.868227 & 0.3932 \\
D(FEPI(-5)) & -0.365335 & 0.280372 & -1.303035 & 0.2040 \\
D(FEPI(-6)) & -0.075805 & 0.269905 & -0.280859 & 0.7810 \\
D(FEPI(-7)) & -0.016444 & 0.275815 & -0.059621 & 0.9529 \\
D(FEPI(-8)) & -0.123150 & 0.240856 & -0.511299 & 0.6135 \\
D(FEPI(-9)) & 0.027492 & 0.197214 & 0.139400 & 0.8902 \\
D(FEPI(-10)) & 0.150716 & 0.178416 & 0.844744 & 0.4060 \\
D(ASPI(-1)) & 1.604898 & 1.672078 & 0.959823 & 0.3460 \\
D(ASPI(-2)) & -0.859928 & 1.656393 & -0.519157 & 0.6080 \\
D(ASPI(-3)) & 2.240866 & 1.867935 & 1.199649 & 0.2411 \\
D(ASPI(-4)) & -1.705830 & 1.799890 & -0.947741 & 0.3520 \\
D(ASPI(-5)) & -0.276189 & 1.705959 & -0.161897 & 0.8726 \\
D(ASPI(-6)) & 0.226107 & 1.787638 & 0.126484 & 0.9003 \\
D(ASPI(-7)) & -3.462583 & 1.833615 & -1.888391 & 0.0702 \\
D(ASPI(-8)) & -0.416468 & 1.869758 & -0.222739 & 0.8255 \\
D(ASPI(-9)) & 0.149475 & 1.906907 & 0.078386 & 0.9381 \\
D(ASPI(-10)) & -2.286809 & 1.912330 & -1.195823 & 0.2426 \\
\hline
\end{tabular}


G. D. K. Kumara \& D. A. I. Dayaratne / Colombo Business Journal, 6/2

\begin{tabular}{|c|c|c|c|c|}
\hline $\mathrm{D}(\mathrm{SP} 500(-1))$ & 5.292847 & 10.23958 & 0.516901 & 0.6096 \\
\hline D(SP500(-2)) & 16.73811 & 11.41984 & 1.465705 & 0.1547 \\
\hline D(SP500(-3)) & -11.63118 & 11.03971 & -1.053576 & 0.3018 \\
\hline D(SP500(-4)) & 10.67702 & 12.48399 & 0.855257 & 0.4002 \\
\hline D(SP500(-5)) & -4.230811 & 11.50631 & -0.367695 & 0.7161 \\
\hline D(SP500(-6)) & -10.23825 & 10.48672 & -0.976306 & 0.3379 \\
\hline D(SP500(-7)) & -0.219702 & 11.01732 & -0.019941 & 0.9842 \\
\hline D(SP500(-8)) & -0.542982 & 9.913403 & -0.054773 & 0.9567 \\
\hline D(SP500(-9)) & -0.207534 & 9.512326 & -0.021817 & 0.9828 \\
\hline D(SP500(-10)) & -6.130741 & 9.354216 & -0.655399 & 0.5180 \\
\hline D(MIMP(-1)) & -255.4479 & 1726.179 & -0.147985 & 0.8835 \\
\hline D(MIMP(-2)) & 1525.534 & 1502.755 & 1.015158 & 0.3194 \\
\hline D(MIMP(-3)) & -183.6187 & 1474.527 & -0.124527 & 0.9019 \\
\hline D(MIMP(-4)) & 744.0227 & 1338.450 & 0.555884 & 0.5830 \\
\hline D(MIMP(-5)) & 1168.639 & 1573.882 & 0.742520 & 0.4644 \\
\hline D(MIMP(-6)) & -1135.029 & 1409.726 & -0.805141 & 0.4280 \\
\hline D(MIMP(-7)) & 746.1222 & 1732.874 & 0.430569 & 0.6703 \\
\hline D(MIMP(-8)) & -1987.807 & 1692.858 & -1.174231 & 0.2509 \\
\hline D(MIMP(-9)) & 3470.724 & 1586.025 & 2.188315 & 0.0378 \\
\hline D(MIMP(-10)) & 179.9297 & 1614.700 & 0.111432 & 0.9121 \\
\hline $\mathrm{D}(\mathrm{TBR}(-1))$ & 99.61794 & 605.5525 & 0.164508 & 0.8706 \\
\hline $\mathrm{D}(\mathrm{TBR}(-2))$ & 57.03112 & 621.0853 & 0.091825 & 0.9275 \\
\hline $\mathrm{D}(\mathrm{TBR}(-3))$ & 314.7677 & 602.9123 & 0.522079 & 0.6060 \\
\hline $\mathrm{D}(\mathrm{TBR}(-4))$ & 880.0807 & 634.6953 & 1.386619 & 0.1773 \\
\hline $\mathrm{D}(\mathrm{TBR}(-5))$ & -873.3719 & 692.0173 & -1.262067 & 0.2181 \\
\hline $\mathrm{D}(\mathrm{TBR}(-6))$ & 1388.816 & 812.1745 & 1.709997 & 0.0992 \\
\hline $\mathrm{D}(\mathrm{TBR}(-7))$ & 175.2090 & 756.1433 & 0.231714 & 0.8186 \\
\hline $\mathrm{D}(\mathrm{TBR}(-8))$ & -1053.694 & 677.3999 & -1.555498 & 0.1319 \\
\hline D(TBR(-9)) & -441.9454 & 670.8001 & -0.658833 & 0.5158 \\
\hline D(TBR(-10)) & 29.85557 & 778.6707 & 0.038342 & 0.9697 \\
\hline D(LIBOR(-1)) & -616.1031 & 2020.122 & -0.304983 & 0.7628 \\
\hline D(LIBOR(-2)) & 2933.688 & 1613.440 & 1.818281 & 0.0806 \\
\hline D(LIBOR(-3)) & -1959.818 & 2125.767 & -0.921934 & 0.3650 \\
\hline D(LIBOR(-4)) & -2771.656 & 2048.130 & -1.353262 & 0.1876 \\
\hline D(LIBOR $(-5))$ & 5108.527 & 2066.715 & 2.471810 & 0.0203 \\
\hline D(LIBOR(-6)) & -2284.926 & 2242.220 & -1.019046 & 0.3176 \\
\hline D(LIBOR(-7)) & -2089.441 & 2026.274 & -1.031174 & 0.3120 \\
\hline D(LIBOR(-8)) & 1395.661 & 1763.599 & 0.791371 & 0.4359 \\
\hline D(LIBOR(-9)) & -88.80891 & 2126.278 & -0.041767 & 0.9670 \\
\hline D(LIBOR(-10)) & 786.3877 & 2187.413 & 0.359506 & 0.7221 \\
\hline D(FOREX $(-1))$ & 140.0786 & 333.3298 & 0.420240 & 0.6778 \\
\hline D(FOREX $(-2))$ & -486.6336 & 309.7361 & -1.571124 & 0.1282 \\
\hline D(FOREX $(-3))$ & 199.5593 & 369.6552 & 0.539853 & 0.5939 \\
\hline D(FOREX(-4)) & -464.1028 & 442.8221 & -1.048057 & 0.3043 \\
\hline D(FOREX(-5)) & 291.3757 & 372.6083 & 0.781989 & 0.4413 \\
\hline D(FOREX(-6)) & -107.6314 & 346.1186 & -0.310967 & 0.7583 \\
\hline D(FOREX(-7)) & 240.4563 & 394.6351 & 0.609313 & 0.5476 \\
\hline D(FOREX $(-8))$ & -219.6198 & 368.8714 & -0.595383 & 0.5567 \\
\hline D(FOREX(-9)) & -36.33456 & 373.9779 & -0.097157 & 0.9233 \\
\hline D(FOREX(-10)) & 155.5656 & 323.2532 & 0.481250 & 0.6344 \\
\hline
\end{tabular}


G. D. K. Kumara \& D. A. I. Dayaratne / Colombo Business Journal, 6/2

\begin{tabular}{|lllll|}
\hline $\mathrm{D}(\mathrm{CCPI}(-1))$ & -160.0619 & 358.4557 & -0.446532 & 0.6589 \\
$\mathrm{D}(\mathrm{CCPI}(-2))$ & 147.7369 & 350.7233 & 0.421235 & 0.6770 \\
$\mathrm{D}(\mathrm{CCPI}(-3))$ & -197.1981 & 384.9250 & -0.512303 & 0.6128 \\
$\mathrm{D}(\mathrm{CCPI}(-4))$ & -94.60120 & 387.9203 & -0.243868 & 0.8092 \\
$\mathrm{D}(\mathrm{CCPI}(-5))$ & 265.0170 & 384.2725 & 0.689659 & 0.4965 \\
$\mathrm{D}(\mathrm{CCPI}(-6))$ & -560.0903 & 390.7079 & -1.433527 & 0.1636 \\
$\mathrm{D}(\mathrm{CCPI}(-7))$ & 537.0710 & 378.2531 & 1.419872 & 0.1675 \\
$\mathrm{D}(\mathrm{CCPI}(-8))$ & -184.6850 & 377.6180 & -0.489079 & 0.6289 \\
$\mathrm{D}(\mathrm{CCPI}(-9))$ & 442.8586 & 343.8421 & 1.287971 & 0.2091 \\
$\mathrm{D}(\mathrm{CCPI}(-10))$ & -231.3272 & 375.1120 & -0.616688 & 0.5428 \\
\hline \hline & & & & \\
$\mathrm{R}-$-squared & 0.800197 & Mean dependent var & 32.50234 \\
Adjusted R-squared & 0.185418 & S.D. dependent var & 2715.411 \\
S.E. of regression & 2450.773 & Akaike info criterion & 18.54548 \\
Sum squared resid & $1.56 \mathrm{E}+08$ & \multicolumn{2}{l}{ Schwarz criterion } & 20.56884 \\
Log likelihood & -911.1832 & F-statistic & 1.301600 \\
Durbin-Watson stat & 2.154677 & Prob(F-statistic) & 0.227216 \\
\hline \hline
\end{tabular}

